\title{
Dynamic corporate culture into vocational education and limited driving element parsed
}

\author{
Gao Jianbo ${ }^{1,}$ a , Liu Yanming ${ }^{1, b}$ \\ ${ }^{1}$ Jiangxi Science \& Technology Normal University, Nanchang, Jiangxi, 330013, P.R. China \\ a gaojianbo1971@163.com, ${ }^{\text {b } 498225491 @ q q . c o m}$
}

Keywords: Corporate culture; vocational education; dynamic analysis; analytic driving element

\begin{abstract}
Into the corporate culture in vocational education, very good to improve the teaching quality of vocational education, improve teaching level vocational education. Vocational education institutions should integrate into the corporate culture of attention from the deepening of the degree of cooperation of enterprises and vocational education institutions, launched various forms of cooperation between schools and enterprises to start, and effectively improve the corporate culture into vocational education level, so as to promote development of vocational education . In this paper, the corporate culture and vocational education are described, analyzed the corporate culture into vocational education and limited dynamic driving element, hoping to help the development of vocational education in China.
\end{abstract}

\section{Introduction}

With the accelerated pace of economic development, China Vocational College wanted the society more and more professional and technical personnel. How to ensure the Higher Colleges of professionalism and technical personnel to meet the requirements of enterprises, it has become a problem of public concern. Integration into the corporate culture in vocational education, can well improve the teaching quality of vocational education, improve teaching level vocational education, to promote the development of vocational education has a very important role.

\section{Culture and Vocational education}

\subsection{Company culture}

Corporate culture refers primarily in the production and management process, gradually formed in the reaction can be very good values and concepts of business situations. Corporate culture for the development of enterprise production and management methods and management system has a very important role, is a concrete manifestation of the spirit of enterprise development [1]. In practice, corporate culture will have a profound impact unknowingly on the behavior of employees. For example, if two conditions are similar to the development of enterprises, the corporate culture is to decide which companies can be guaranteed better development. Visible, corporate culture has an important impact on enterprise development and decay.

\subsection{Vocational education}

The concept of vocational education from the eighties of last century developed, which is mainly due to the pursuit of business professionals began to develop and flourish in. More famous modern vocational education in college, almost all of the well-known enterprise creation. In particular, vocational education mainly refers to the fundamental basis for the development of education, the students' professional skills and professional quality of education activities. The main objective is to develop vocational education to meet the needs of production and management professionals, this talent has strong professional viability. Implementation of vocational education and general education also have quite different, vocational education institutions more generally to carry out on-site teaching methods, base training methods, internship methods. In addition, the management of vocational education in the teaching mode is usually by way of school-enterprise cooperation were 
education, including in employment in three ways, namely, the employment contract training, both to choose the way of employment, schools recommended method to increase employment. Wherein the order training in vocational education Employment larger proportion.

\section{Dynamic corporate culture into Vocational Education}

According to the survey found that the majority of our vocational education institutions have ignored the presence of professional quality education. This is mainly because companies more students have more professional skills requirements, and for the students of professional quality requirements are lower. But when the students began to work, they often exhibit low professional quality, not well adapted to the corporate culture phenomenon. This development of vocational education is very unfavorable. So, how to solve the case of professional quality education and professional education disjointed, improve teaching quality in vocational education institutions has become a problem for business and education of common concern [2]. And the corporate culture into vocational education, so that students in vocational skills learning phase contacts and understand the business culture is having a good effect. Specifically, the corporate culture into the dynamic of vocational education is mainly reflected in the following aspects.

\subsection{Corporate culture into vocational education is an inherent requirement of the development of students}

First, the corporate culture into vocational education is an inherent requirement to better promote student development. In vocational education, corporate culture as the basis, quality education can be effectively targeted to help students better adapt to future professional life, promote their sustainable development. After an investigation found that some students with good professional skills, but the lack of professional quality, so in practice, are rarely carried out creative work, giving their own development created obstacles. At the same time, a good professional quality but also an inherent requirement of entrepreneurship students. At present, the students start their own businesses is encouraged, and supportive of, but to conduct business not only requires students to have a strong professional ability, but to have a good overall quality, so as to promote entrepreneurship work better start.

\subsection{Corporate culture into vocational education is to meet the business requirements of an} objective need for talent

Into the corporate culture in vocational education can better meet the objective needs of companies for talent. At present, enterprises need for talent has not only satisfied with the talents with professional ability, and talent for teamwork, professionalism and so has a higher demand. This is mainly with the development of science and technology, pure technical personnel can not meet the needs of enterprises, practical and applied talents more and more enterprises of all ages, and in the integration of vocational education can be a good corporate culture to improve students' comprehensive quality, for the students to become application and practical talent to create a good platform.

\subsection{Corporate culture into vocational education is an effective means to enhance the level of teaching}

Integration into the corporate culture in vocational education for enhancing the teaching level vocational education also has a very big help. In practice, vocational colleges in the conduct of professional quality education, mainly taken the traditional didactic way, this way more boring, difficult to arouse the interest of students and the corporate culture into vocational education, it is very easy stimulate students' enthusiasm for learning, help students feel better future professional life, so as to effectively improve the teaching effectiveness of vocational education.

\section{Corporate culture into the driving element analytical vocational education}

In vocational education redundancy corporate culture can effectively improve the overall quality of students, improve their teaching. In practice, a combination of both in order to enhance the effect, 
the following elements from the perspective of the drive into the Career Education of corporate culture analysis.

\subsection{Enhance the level of cooperation of enterprises and vocational education institutions}

Deepen the level of cooperation between enterprises and vocational education is to promote corporate culture to better integrate into the key vocational education. First, companies demand for talent is the source of development of vocational education, is also strong support for the development of vocational education. Enterprises and schools can jointly building personnel training bases, and schools together to create a real professional environment, improve teaching quality in vocational education institutions. At the same time, schools and businesses can sign "Order" training model, students in the training process, companies can join the influence of corporate culture, teaching students targeted intervention, students after graduation directly into enterprises. This approach not only solves the problem of student employment, and because of the students' training targeted to enable students to earlier contact with the corporate culture, so students are better adapted to the development of enterprises, directly taking the place, so reduces the run-time businesses and students.

\subsection{Launched various forms of school-enterprise cooperation}

Business and vocational education and training institutions also launched various forms of cooperation to promote protection of the corporate culture to better integrate into vocational education. In practice, it can conduct cooperation in the following aspects between businesses and schools.

\subsection{To carry out personnel training cooperation conference}

In the school-enterprise cooperation mode, carry out personnel training cooperation conference is a very important way of cooperation. Through personnel training cooperation conference for vocational education institutions, it can be more targeted and practical training applied talent, and for enterprises, through cooperation, effectively improve the professional quality of their own employees, workers of enterprises the team structure.

\subsection{Strengthening Training Base Construction}

In vocational education, the construction of good training base for improving the quality of education is very important and help to better integrate into the corporate culture guarantee vocational education. But at the same time, since vocational education institutions limited their size and financial resources, it is difficult to carry out a full professional training base construction, this time through the enterprise and effective cooperation in order to establish training base to help enterprises under a very good development. While enterprises in the process of personnel training, and targeted intervention to obtain their own development needs of talent, and ultimately achieve a win-win situation. In addition, the training base can solve the shortcomings brought enclosed teaching to help students better understand the business development, familiar with the corporate culture to improve the quality of vocational education personnel.

\subsection{Strengthen personnel exchange mechanism}

Strengthen personnel exchange mechanism mainly includes the following aspects: (1) vocational education institutions can choose good teachers into the enterprise to exercise, to understand the business of actual production, thereby increasing teachers' practical ability; (2) vocational education institutions to select excellent enterprise employees in school part-time teachers work to improve teachers; cooperation between (3) and businesses, to help companies better train employees [3].

\section{5. conclusion}

Integration into the corporate culture in vocational education can effectively improve the overall quality of students, improve the teaching level, to help students better development. In practice, vocational education institutions to integrate into the corporate culture, pay attention to the degree of cooperation from companies deepen and vocational education institutions, launched various forms of cooperation between schools and enterprises to start, and effectively improve the corporate culture into vocational education level, thus promote the development of vocational education. 
This article is one of the results of Jiangxi 2015 annual art and science project "corporate culture into the context of the internet and the Path of Vocational Education Strategy (YG2015058)", the corresponding author Gao Jianbo.

\section{References}

[1]. Hu Yamei learn the corporate culture help Professional Training Paradigm [J]. Huanggang Vocational and Technical College, 2014,06: 15-18.

[2]. Tingting inherent logic of Enterprise Cultural Education and Vocational Education [J] Career Horizon, 2014,10: 23-24 + 27.

[3]. Wu Keyun of Vocational Education campus culture and enterprise culture fusion of nature [J] Modern Enterprise Education, 2011,02: 33-34. 